Community Service | Management and Economics

\title{
Pelatihan Pembuatan Laporan Keuangan Sederhana Bagi Pemuda di Kecamatan Lubuk Alung Sebagai Upaya Pembekalan Keterampilan Wirausaha dan Penguatan UMKM
}

\author{
Thesa Alif Ravelby $^{1}$, Agus Nurofik ${ }^{1}$, Dessy Trismiyanti ${ }^{1}$ \\ ${ }^{1}$ Sekolah Tinggi Ilmu Ekonomi Perdagangan, Padang. Sumatera Barat, Indonesia.
}

Article History

Received:

17.01.2020

Revised:

13.02.2020

Accepted:

27.03.2020

*Corresponding Author:

Agus Nurofik

Email:

agsnin@gmail.com

This is an open access article, licensed under: $\mathrm{CC}-\mathrm{BY}-\mathrm{SA}$
Abstrak: Para pemuda yang di Kecamatan Lubuk Alung tergolong para pemuda aktif yang beberapa diantaranya berinisiatif berwirausaha skala mikro. Semangat para pemuda berwirausaha ditindaklanjuti oleh tim Pengabdian Kepada Masyarakat STIE Perdagangan dengan membantu mereka mengatasi beberapa persoalan yang umumnya dialami oleh usaha khususnya di bidang laporan keuangan. Oleh sebab itulah pengabdian masyarakat ini dilaksanakan dengan tujuan membantu unruk memulai usaha dalam pencatatan keuangan yang rapi dan benar melalui penyampaian ilmu dasar-dasar keuangan. Metode yang dipilih dengan cara memberikan penyuluhan dan pelatihan. Hasil dari kegiatan pengabdian masyarakat ini adalah panduan praktis dan sederhana berupa pedoman bagi usaha mikro dalam membuat laporan keuangan sederhana yang di aplikasi dengan microsoft excel yang terangkum dalam bentuk materi PKM STIE Perdagangan.

Kata Kunci: Laporan Keuangan, Pengabdian Masyarakat, Usaha Mikro.

Training on Making Simple Financial Statements for Youth in kecamatan Lubuk Alung as an Effort to Equip Entrepreneurial Skills and Strengthening of UMKM

Abstract: The youths in Kecamatan Lubuk Alung are classified as active youths, some of whom have initiated micro-scale entrepreneurship. The spirit of entrepreneurial youth was followed up by the Community Service team of STIE Perdagangan by helping them overcome some of the problems commonly experienced by businesses, especially in the field of financial reporting. That is why this community service is carried out with the aim of helping to start a business in recording neat and correct financials through the delivery of basic financial knowledge. The method chosen is by providing counseling and training. The results of this community service activity are practical and simple guidelines in the form of guidelines for micro businesses in making simple financial reports that are applied with Microsoft Excel, which are summarized in the form of PKM STIE Perdagangan.

Keywords: Community Services, Financial Statements, Micro Business. 


\section{Pendahuluan}

\subsection{Analisa Situasi}

Sebuah kecamatan di Kabupaten Padang Pariaman, Sumatra Barat, Indonesia. Meskipun hanya berstatus kecamatan, Lubuk Alung merupakan salah satu pusat pertumbuhan ekonomi penting di Kabupaten Padang Pariaman, dan menjadi kota penyangga bagi wilayah metropolitan Palapa (Padang - Lubuk Alung - Pariaman). Berdasarkan data Badan Pusat Statistik Padang Pariaman [1], Kecamatan Lubuk Alung terletak pada berbatasan pada wilayah sebagai berikut:

- Sebelah utara berbatas dengan Kecamatan 2x11 Kayu Tanam dan Sintuk Toboh Gadang.

- Sebelah selatan berbatas dengan Kecamatan Batang Anai.

- Sebelah timur berbatas dengan Kabupaten Solok dan Bukit Barisan.

- Sebelah barat berbatas dengan Kecamatan Sintuk Toboh Gadang.

Berdasarkan data BPS Padang Pariaman [2], di Kecamatan Lubuk Alung pada tahun 2017 masih cukup besar dengan komposisi penduduk usia produktif (15-64 tahun) sebanyak 28.329 jiwa dan jumlah penduduk yang bekerja sebanyak 12.799 jiwa. Dengan demikian sisanya sebesar 15.530 atau $54,82 \%$ jiwa penduduk usia produktif terkategori belum memiliki pekerjaan. Masih banyaknya jumlah penduduk usia produktif yang belum memiliki pekerjaan merupakan permasalahan yang tidak hanya menjadi tanggungjawab bagi pemerintah dalam menyediakan lapangan pekerjaan tetapi persoalan pengangguran ini merupakan permasalahan kesejahteraan sosial bersama-sama antara masyarakat, lembaga pendidikan tinggi, dunia usaha dengan pemerintah supaya hendaknya bersinergi mengatasi permasalahan penyediaan lapangan pekerjaan bagi penduduk yang belum memiliki pekerjaan memadai dalam rangka memenuhi kebutuhan hidupnya.

Pada lingkungan kemasyarakatan terdapat banyak organisasi pemuda yang menjadi tempat berkumpul dan berhimpun para pemuda dengan segala aktivitas dalam meraih kesamaan visi, misi dan tujuan berorganisasi sehingga terjalin kebersamaan dalam melaksanakan kegiatan positif untuk kepentingan individu-individu yang tergabung dalam organisasi tersebut. Pada lingkungan kemasyarakatan terdapat banyak organisasi pemuda yang menjadi tempat berkumpul dan berhimpun para pemuda dengan segala aktivitas dalam meraih kesamaan visi, misi dan tujuan berorganisasi sehingga terjalin kebersamaan dalam melaksanakan kegiatan positif untuk kepentingan individuindividu yang tergabung dalam organisasi tersebut.

Pada lingkungan kemasyarakatan terdapat banyak organisasi pemuda yang menjadi tempat berkumpul dan berhimpun para pemuda dengan segala aktivitas dalam meraih kesamaan visi, misi dan tujuan berorganisasi sehingga terjalin kebersamaan dalam melaksanakan kegiatan positif untuk kepentingan individu-individu yang tergabung dalam organisasi tersebut. Jumlah penduduk dengan sebaran usia produktif 15 tahun ke atas di Kecamatan Lubuk Alung dipaparkan pada Tabel 1 di bawah ini:

Tabel 1. Jumlah Sebaran Usia Produktif (15-44 tahun) yang Dikategorikan Pemuda di Kecamatan Lubuk Alung Tahun 2017

\begin{tabular}{|c|c|c|c|c|}
\hline \multirow{2}{*}{ No } & \multirow{2}{*}{$\begin{array}{c}\text { Kelompok } \\
\text { Usia }\end{array}$} & \multicolumn{2}{|c|}{ Jenis Kelamin } & \multirow{2}{*}{ Jumlah } \\
\hline & & Laki-laki & Perempuan & \\
\hline 1 & $15-19$ & 2215 & 2042 & 4257 \\
\hline 2 & $20-24$ & 1834 & 1812 & 3646 \\
\hline 3 & $25-29$ & 1613 & 1587 & 3200 \\
\hline 4 & $30-34$ & 1594 & 1523 & 3117 \\
\hline 5 & $35-39$ & 1408 & 1486 & 2894 \\
\hline 6 & 40-44 & 1513 & 1437 & 2950 \\
\hline \multicolumn{2}{|c|}{ Jumlah } & 10177 & 9887 & 20064 \\
\hline
\end{tabular}

Jumlah penduduk dengan kisaran usia produktif (15 - 44 tahun) di Kecamatan Lubuk Alung berjumlah 20.064 jiwa. Tahap usia 15 tahun merupakan usia remaja yang rentan terhadap pengaruh dari lingkungan luar sedangan usia 44 tahun merupakan tahap kematangan seorang pemuda. Kisaran 
usia pemuda dari 13 sampai 45 tahun menjadi wadah yang tepat bagi para pemuda untuk saling sinergi dalam mengembangkan jati diri, potensi, kreativitas bagi anggota yang pemula atau junior dan sarana bagi senior untuk memberi pengarahan, pembinaan dan pengajaran bagi anggota pemuda yang masih junior terutama dalam pembinaan kesejahteraan sosial baik individu, kelompok dan masyarakat.

Dalam usaha meningkatkan kesejahteraan, Pemuda Kecamatan Lubuk Alung berusaha menjalankan kegiatan ekonomi produktif baik secara individu maupun bersama-sama. Pemuda Kecamatan Lubuk Alung menyadari bahwa bersinergi dengan menjalin kerjasama dengan perguruan tinggi Sekolah Tinggi Ilmu Ekonomi Perdagangan (STIE-P) sangat penting dijalani demi meningkatkan pengetahuan mereka di bidang ekonomi produktif. Permasalahan yang dihadapi oleh mereka adalah persoalan-persoalan yang umumnya dihadapi oleh jenis usaha mikro dan pemula dalam berbisnis antara lain persoalan manajemen pemasaran, pengadministrasian dan akuntabilitas keuangan, manajemen produksi, kualitas SDM dan lain-lain.

Membuka usaha baru tidak mungkin tanpa ada rencana sebelumnya. Rencana tertulis betapapun sederhananya harus ada. Namun, wirausaha baru yang tidak mau atau tidak mampu menulis rencana tertulis tersebut karena berbagai alasan. Perencanaan yang tidak tertulis pasti sudah ada rekayasa dalam pikiran, yaitu suatu rekayasa secara sederhana tentang jawaban dari berbagai pernyataan antara lain, usaha apa yang akan dibuka, mengapa memilih usaha tersebut, di mana lokasinya, siapa konsumennya, darimana sumber modal dsb. Dinyatakan oleh David H.Bangs Jr bahwa seorang pengusaha yang tidak bisa membuat perencanaan sebenarnya merencanakan kegagalan. Suatu rencana kerja yang dibuat tertulis dan resmi guna menjalankan perusahaan (business plan) merupakan perangkat tepat untuk memegang kendali perusahaan dan menjaga agar fokus usaha.

Untuk itu, maka tim PKM Sekolah Tinggi Ilmu Ekonomi Perdagangan (STIE-P) merasa bertanggungjawab untuk bersama-sama dilakukan pelatihan pembuatan laporan keuangan sederhana bagi pemuda di Kecamatan Lubuk Alung sebagai upaya pembekalan keterampilan wirausaha dan penguatan UMKM.

\subsection{Perumusan Mitra}

Rumusan masalah yang akan dibahas adalah:

1. Kurangnya pemahaman dan pengetahuan para pemuda tentang penting laporan keuangan sederhana.

2. Lemahnya administrasi dan pengelolaan serta akuntabilitas keuangan yang terkesan tidak tercatat secara terstruktur dan terorganisir secara sistematis antara pengeluaran dan pemasukan.

\subsection{Tujuan Pengabdian Masyarakat}

Tujuan yang ingin dicapai dari kegiatan pengabdian pada masyarakat ini adalah:

1. Membekali pemuda di Kecamatan Lubuk Alung agar memiliki pemahaman dan pengetahuan tentang pengtingnya laporan keuangan sederhana.

2. Membantu memberikan pengetahuan dan pemahaman tentang ilmu keuangan sederhana supaya terwujudnya sistem pencatatan keuangan yang terorganisir secara rapi dan sistematis.

3. Memberikan contoh penyusunan secara secara jelas dan mudah dipahami pembuatan laporan keuangan sederhana untuk jenis usaha mikro dan bisnis pemula.

4. Ikut membantu dalam membina para pemuda dengan memberikan pendidikan dasar-dasar akuntansi sederhana untuk bisnis pemula.

\subsection{Manfaat Kegiatan}

Manfaat yang diharapkan dari kegiatan pegabdian masyarakat ini adalah:

1. Peserta memahami pengetahuan dasar-dasar laporan keuangan sederhana yang cocok untuk diterapkan pada bisnis pemula dan usaha mikro.

2. Peserta menyadari akan pentingnya pengelolaan dan administrasi pencatatan keuangan yang terorganisir secara rapi dan sistematis sehingga terwujud laporan keuangan yang akuntabel dan transparan.

3. Peserta mengetahui dan memahami cara penyusunan sederhana laporan keuangan yang benar seseuai kaidah-kaidah akuntansi.

4. Peserta menyadari akan pentingnya memiliki pengetahuan laporan keuangan sederhana untuk dipraktekkan pada usahanya. 


\section{Tinjauan Pustaka}

\subsection{Pengertian Laporan Keuangan}

Pengertian laporan keuangan adalah hasil akhir dari proses pencatatan transaksi keuangan suatu perusahaan yang menunjukkan kondisi keuangan perusahaan tersebut pada satu periode akuntansi dan merupakan gambaran umum mengenai kinerja suatu perusahaan. Pendapat lain mengatakan bahwa laporan keuangan adalah produk akhir proses akuntansi suatu perusahaan dalam satu periode tertentu dimana informasi di dalamnya merupakan hasil pengumpulan dan pengolahan data keuangan, dengan tujuan untuk membantu perusahaan membuat keputusan atau kebijakan yang tepat. Proses penyusunan financial statement menggunakan berbagai sumber data, mulai dari faktur, bon, nota kredit, laporan, bank dan lain sebagainya. Semua data asli transaksi keuangan tersebut digunakan untuk mengisi buku perkiraan dan sebagai bukti keabsahan transaksi.

Laporan Keuangan Konsolidasian, di mana menurut Keputusan Ketua Bapepam dan LK Nomor: Kep-347/BL/2012 tanggal 25 Juni 2012, adalah bahwa Laporan keuangan konsolidasi adalah laporan keuangan suatu kelompok usaha yang disajikan sebagai suatu entitas ekonomi tunggal yang menggabungkan seluruh entitas yang dikendalikan oleh emiten atau perusahaan publik, termasuk entitas bertujuan khusus (EBK) [3].

Menurut Standar Akuntansi Keuangan (SAK) laporan keuangan adalah bagian dari proses pelaporan keuangan yang lengkap, meliputi; neraca, laporan laba rugi, laporan perubahan posisi keuangan (arus kas, atau arus dana, catatan, dan laporan lain) serta materi penjelasan yang merupakan bagian integral darinya [4].

Pengertian laporan keuangan menurut para ahli sebagai berikut:

- Menurut M. Sadeli [5], pengertian laporan keuangan adalah hasil dari proses akuntasi dan informasi histories yang di dalamnya terdapat proses identifikasi, pengukuran, dan laporan informasi ekonomi sebagai bahan pertimbangan dalam mengambil keputusan yang tepat.

- Menurut Sjadzali [6], pengertian laporan keuangan adalah proses akuntansi yang dapat digunakan sebagai alat untuk mengkomunikasikan data keuangan.

- Menurut Kasmir [7], financial statement adalah suatu laporan yang menunjukkan kondisi keuangan perusahaan saat ini atau periode berikutnya.

- Menurut Sukirno [8], pengertian laporan keuangan adalah suatu laporan yang menggambarkan kondisi keuangan dan hasil usaha suatu perusahaan pada jangka waktu tertentu.

Dari definisi diatas, merupakan ringkasan dari suatu proses pencatatan, merupakan suatu ringkasan dari transaksi-transaksi keuangan yang terjadi selama tahun buku yang bersangkutan.

\subsection{Tujuan Laporan Keuangan}

Pembuatan laporan keuangan oleh suatu perusahaan tentunya ada tujuan yang ingin dicapai. Adapun beberapa tujuan umum pembuatan laporan keuangan adalah sebagai berikut:

1. Untuk membantu perusahaan dalam proses pengambilan keputusan. Informasi mengenai kondisi keuangan perusahaan dapat membantu suatu perusahaan sebagai bahan evaluasi dan perbandingan dampak keuangan yang terjadi akibat dari suatu keputusan ekonomi.

2. Untuk membantu perusahaan dalam menilai dan memprediksi pertumbuhan bisnis di masa depan. Dengan adanya informasi keuangan, maka suatu perusahaan dapat menilai bagaimana kondisi perusahaan di masa sekarang dan meramalkan kondisi perusahaan di masa mendatang.

3. Untuk menilai aktivitas pendanaan dan operasi perusahaan. Informasi mengenai kondisi keuangan juga dapat membantu suatu perusahaan dalam menilai aktivitas investasi dan kemampuan operasional perusahaan tersebut pada satu periode tertentu.

\subsection{Fungsi Laporan Keuangan}

Pada dasarnya laporan keuangan berfungsi sebagai alat untuk membantu perusahaan dalam menilai kondisi keuangan perusahaan secara umum. Adapun beberapa fungsinya adalah sebagai berikut [9]: 
1. Sebagai Bahan Review

Laporan keuangan dapat memberikan data atau informasi yang komprehensif tentang posisi keuangan perusahaan. Hal ini bisa menjadi ulasan mengenai kondisi perusahaan secara menyeluruh, khususnya kondisi keuangan (aset, utang, biaya operasional, dan lain-lain).

2. Sebagai Pedoman Membuat Keputusan

Salah satu fungsi penting dibuatnya laporan mengenai kondisi keuangan perusahaan adalah sebagai bahan pertimbangan dalam mengambil keputusan penting bagi perusahaan.

3. Membantu Menciptakan Strategi Baru

Selain membantu proses pengambilan keputusan penting, laporan keuangan juga dapat dipakai untuk menciptakan strategi baru oleh perusahaan dalam upaya meningkatkan performa usahanya.

4. Meningkatan Kredibilitas Perusahaan

Perusahaan yang membuat laporan keuangan menunjukkan bahwa perusahaan tersebut telah menerapkan suatu sistem perekapan data yang terpercaya, akurat, dan tidak sembarangan dalam mengambil keputusan. Para pemegang saham tentu lebih percaya menginvestasikan uang mereka kepada perusahaan yang dipercaya dan memiliki kredibilitas yang baik.

\subsection{Jenis-jenis Laporan Keuangan}

Setidaknya ada 4 macam laporan keuangan yang sering dipakai untuk melakukan analisis terhadap kondisi keuangan perusahaan [10], yaitu:

1. Laporan Laba Rugi (profit and lost statement)

Laporan laba rugi adalah suatu laporan yang menjelaskan tentang kinerja keuangan suatu entitas bisnis dalam satu periode akuntansi. Di dalam laporan ini terdapat informasi mengenai unsur-unsur pendapatan dan beban perusahaan sehingga diketahui laba atau rugi bersih.

\section{Laporan Perubahan Modal (capital statement)}

Laporan perubahan modal adalah jenis laporan yang di dalamnya terdapat informasi tentang perubahan modal atau ekuitas perusahaan pada periode tertentu. Laporan ini dapat memberikan informasi seberapa besar terjadi perubahan modal dan apa saja yang menyebabkan terjadinya perubahan tersebut.

3. Laporan Neraca (balance sheet)

Laporan neraca adalah laporan yang menjelaskan informasi kondisi keuangan suatu entitas bisnis pada tanggal tertentu. Dari laporan ini kita dapat mengetahui berapa jumlah aktiva (harta, aset), kewajiban (utang), dan ekuitas perusahaan.

4. Laporan Arus Kas (cash flows)

Laporan arus kas adalah financial statement suatu entitas bisnis yang dipakai untuk menunjukkan aliran masuk dan keluar kas perusahaan pada suatu periode akuntansi. Laporan ini juga menjadi alat pertanggungjawaban cash flows selama periode pelaporan.

\subsection{Microsoft Excel}

Microsoft Excel adalah sebuah program atau aplikasi yang merupakan bagian dari paket instalasi Microsoft Office, berfungsi untuk mengolah angka menggunakan spreadsheet yang terdiri dari baris dan kolom untuk mengeksekusi perintah. Microsoft Excel telah menjadi software pengolah data / angka terbaik di dunia, selain itu Microsoft Excel telah didistribusikan secara multi-platform.

Microsoft Excel digunakan di berbagai bidang pekerjaan, baik usaha kecil maupun perusahaan berskala internasional. Adapun beberapa fungsi dan kegunaan Microsoft Excel adalah sebagai berikut:

1) Membuat, mengedit, mengurutkan, menganalisis, meringkas, dan memformat data serta grafik.

2) Membuat catatan keuangan dan anggaran keuangan.

3) Menghitung dan mengelola investasi, pinjaman, penjualan, inventaris, dll.

4) Melakukan analisis dan riset harga.

5) Melakukan perhitungan statistika.

6) Membantu berbagai sektor bisnis untuk mempermudah melakukan laporan keuangan.

7) Membuat daftar nilai sekolah maupun universitas.

8) Konversi mata uang.

9) Membuat grafik persamaan matematika. 
10) Membuat program Excel dengan Visual Basic.

11) Melakukan penelitian dengan berbagai metode penelitian.

12) Sarana pembelajaran komputer dan logika.

\section{Metode Kegiatan}

\subsection{Permasalahan}

Salah satu persoalan adalah lemahnya administrasi dan pengelolaan serta akuntabilitas keuangan yang terkesan tidak tercatat secara terstruktur dan terorganisir secara sistematis antara pengeluaran dan pemasukan. Sehingga seringkali tercampur aduk antara keuangan pribadi, bersama dan organisasi. Untuk mengatasi persoalan tersebut, tim PKM Sekolah Tinggi Ilmu Ekonomi Perdagangan (STIE-P) memcoba membantu mitra dengan memberikan pengetahuan dan pemahaman pentingnya bagaimana menjalankan bisnis dengan pengaturan sistem pengadministrasian dan pengelolaan keuangan secara transparan sehingga terwujud akuntabilitas dalam pembuatan laporan keuangan meski secara sederhana dan berskala mikro dan pemula.

\subsection{Pemecahan Masalah}

Permasalah yang berkaitan dengan pengelolaan laporan keuangan sederhana memerlukan pendekatanpendekatan secara teoritis dan praktis agar wawasan dan pengetahuan para pelaksanaan pembukuan dan keuangan. Pelatihan bertujuan untuk membekali para pemuda di Kecamatan Lubuk Alung pembukuan dan keuangan dengan pengetahuan dan pemahaman dalam mengelola dan membuat laporan keuangan sederhana dengan menggunakan sistem sederhana yaitu Microsoft Excel.

\subsection{Khalayak Sasaran}

Khalayak sasaran pelatihan pembuatan laporan keuangan sederhana bagi pemuda di Kecamatan Lubuk Alung sebagai upaya pembekalan keterampilan wirausaha dan penguatan UMKM, dengan jumlah pemuda yang diikutsertakan dalam pelatihan ini sebanyak 30 orang.

Tabel 2. Daftar Nama Peserta

\begin{tabular}{clcl}
\hline No & Nama & No & Nama \\
\hline 1 & Novri Masyudi & 16 & Roki \\
\hline 2 & Mulyadi & 17 & Edi Nazar \\
\hline 3 & Alfiferia & 18 & Ronaldi \\
\hline 4 & Hendriko & 19 & Ahmad Fauzi \\
\hline 5 & Jon Efendi & 20 & Yudi \\
\hline 6 & Ardion & 21 & Roni \\
\hline 7 & Yoga Hendrico & 22 & Bimo \\
\hline 8 & Zainal & 23 & Zetra \\
\hline 9 & Riko & 24 & Irfan \\
\hline 10 & Firman & 25 & Erik \\
\hline 11 & Cipto & 26 & Randa \\
\hline 12 & Harry & 27 & Andre \\
\hline 13 & Febri & 28 & Agung \\
\hline 14 & Tanjung & 29 & Afdal \\
\hline 15 & Iqbal & 30 & Abdullah \\
\hline
\end{tabular}

\subsection{Perencanaan Materi}

Para peserta para pemuda Kecamatan Lubuk Alung akan diberikan materi pengetahuan tentang akuntasi keuangan sederhana yang meliputi dasar-dasar akuntansi sederhana tentang sistem pencatatan pemasukan dan pengeluaran sederhana (catatan aliran kas/cash flow) sehingga terbentuknya pencatatan keuangan yang sederhana, akuntabel dan transparan. Selanjutnya setelah 
pengetahuan dasar-dasar akuntansi diberikan, materi dilanjutkan dengan pemberian pengetahuan dan ketrampilan penyusunan secara sederhana dan mudah tentang pembuatan laporan keuangan. Pengenalan aplikasi Microsoft Excel dan latihan penyusunan laporan keuangan sederhana dengan menggunakan aplikasi Microsoft Excel.

\subsection{Waktu dan Tempat Pelaksanaan}

Pelaksanaan kegiatan pengabdian masyarakat ini dilaksanakan pada pekan ke-3 bulan November 2019, bertempat di Aula Kecamatan Lubuk Alung Kabupaten Padang Pariaman. Peserta 30 orang merupakan pemuda yang berasal dari beberapa kecematan Lubuk Alung, Padang Pariaman.

\subsection{Pemateri dan Pelaksana Pada Kegiatan Pelatihan}

Pelatihan diberikan oleh dosen Sekolah Tinggi Ilmu Ekonomi Perdagangan.

Tabel 3. Daftar Nama Narasumber dan Instruktur Kegiatan Pegabdian

\begin{tabular}{clc}
\hline No & \multicolumn{1}{c}{ Nama } & Tugas dalam Tim \\
\hline 1 & Yoserizal, S.Hi., MM & Pemateri \\
\hline 2 & Sutiyem, SE., MM & Pemateri \\
\hline 3 & Jasmalinda, SH., MH & Moderator \\
\hline 4 & Trimardi Jayaputra, SE., M.Si & Moderator \\
\hline 5 & Jumiatul Mulya, S.Pd., M. Hum & Instruktur \\
\hline
\end{tabular}

\section{Hasil dan Pembahasan}

\subsection{Deskripsi Peserta Pemuda Kecamatan Lubuk Alung}

Mitra pengabdian masyarakat yang menjadi obyek dalam kegiatan pelatihan keuangan sederhana untuk pemula dalam berwirausaha adalah para pemuda yang belum bekerja di Kecamatan Lubuk Alung.

Pemuda yang belum bekerja di Kecamatan Lubuk Alung yang menjadi peserta dalam kegiatan pengabdian masyarakat Pelatihan Keuangan Sederhana ini dihadiri oleh kurang lebih 30 peserta yang diundang. Latar belakang pendidikan para peserta didominasi oleh para pemuda yang baru menamatkan pendidikannya dari SLTA atau SMK, sedikit yang sedang melanjutkan ke perguruan tinggi (7 orang), 3 orang lulusan universitas, serta hanya 5 orang peserta yang berencana buka usaha seperti membuka kios/warung pulsa dan berdagang. Jumlah peserta dapat dilihat pada Tabel 1 sedangkan perincian para peserta diperlihatkan pada Tabel 4.

Tabel 4. Jumlah Peserta Pengabdian Masyarakat

\begin{tabular}{rlc}
\hline No & \multicolumn{1}{c}{ Peserta } & Jumlah \\
\hline 1 & Lulusan SLTA/SMK & 11 \\
\hline 2 & Lulusan Universitas & 3 \\
\hline 3 & Mahasiswa & 7 \\
\hline 4 & Rencana Buka Usaha & 5 \\
\hline 5 & Tanpa Keterangan & 4 \\
\hline & Total & 30 \\
\hline
\end{tabular}

\subsection{Hasil Pengabdian Masyarakat}

Melalui pelatihan keuangan sederhana dengan menggunakan aplikasi Microsoft Excel bagi pemuda di kecamatan Lubuk Alung, maka diperoleh hasil seperti yang ditunjukkan pada Tabel 5. 
Tabel 5. Hasil Kegiatan Pelatihan Keuangan Sederhana

\begin{tabular}{|c|c|c|c|}
\hline No & Kegiatan & Respon & Keterangan \\
\hline 1 & $\begin{array}{l}\text { Pencatatan (Buku } \\
\text { Harian/Jurnal) }\end{array}$ & Sangat Bagus & $\begin{array}{l}\text { Peserta memahami pencatatan yang jelas } \\
\text { semua sumber transaksi keuangan di buku kas } \\
\text { harian (jurnal). }\end{array}$ \\
\hline 2 & $\begin{array}{l}\text { Pengelompokan } \\
\text { (Buku Besar) }\end{array}$ & Sangat Bagus & $\begin{array}{l}\text { Peserta memahami penting untuk memisahkan } \\
\text { antara keuangan pribadi dan usaha, untuk } \\
\text { mengetahui apa-apa saja yang termasuk jenis } \\
\text { harta (aktiva), hutang (pasiva), modal, beban, } \\
\text { hasil penjualan/pendapatan. }\end{array}$ \\
\hline 3 & $\begin{array}{l}\text { Aplikasi } \\
\text { Microsoft Excel }\end{array}$ & Sangat Bagus & $\begin{array}{l}\text { Peserta mengetahui cara menjalankan aplikasi } \\
\text { Microsoft Excel dalam pembuatan laporan } \\
\text { keuangan sederhana. }\end{array}$ \\
\hline 4 & $\begin{array}{l}\text { Pembuatan } \\
\text { Laporan } \\
\text { Keuangan pada } \\
\text { Microsoft Excel }\end{array}$ & Sangat Bagus & $\begin{array}{l}\text { Peserta mengetahui dan memahami bagaimana } \\
\text { cara membuat laporan keuangan sederhana } \\
\text { dengan menggunakan aplikasi Microsoft } \\
\text { Excel secara cepat dan praktis. }\end{array}$ \\
\hline
\end{tabular}

\subsection{Pembahasan}

Berdasarkan kendala-kendala yang ada maka tim PKM Sekolah Tinggi Ilmu Ekonomi Perdagangan (STIE-P) menyusun pedoman dan langkah-langkah simpel dan mudah dipahami dalam pembuatan laporan keuangan yang sederhana.

Pedoman yang harus diikuti adalah:

1) Keuangan usaha harus terpisah dari keuangan pribadi

2) Objektivitas pencatatan transaksi harus berdasarkan sumber/dokumen yang nyata seperti faktur, kuitansi/nota dan tagihan dari pemasok

3) Kegiatan yang dicatat diukur dengan uang

4) Rapi dan mudah dalam penyajian jika diperlukan

Harahap [3] menyatakan bahwa proses akuntansi adalah proses pengolahan data yang secara umum langkah-langkahnya sebagai berikut:
1) Transaksi disetujui
2) Transaksi dilaksanakan
3) Transaksi dicatat secara kronologis
4) Catatan diklarifikasikan
5) Informasi dilaporkan

Berdasarkan langkah tersebut, maka secara garis besar pembuatan laporan keuangan sederhana dapat diuraikan berdasarkan langkah-langkah sebagai berikut:

1. Pencatatan (Buku Harian/Jurnal)

Setelah transaksi disetujui baik secara lisan maupun tertulis kemudian dilaksanakan maka selanjutnya dilakukan pencatatan dengan jelas semua sumber transaksi keuangan pada buku kas harian (jurnal) dengan membuat kolomkolom tanggal, uraian, uang masuk dan uang keluar. Karena transaksi keuangan usaha mikro sederhana maka sistem pencatatan ditulis dalam satu buku harian (jurnal) saja sudah cukup. Simpan bukti transaksi seperti kuitansi, nota pembelian, faktur penjualan, tagihan dari supplier lalu perhatikan kecocokan antara jumlah uang tunai dengan jumlah saldo akhir buku kas.

2. Pengelompokan (Buku Besar) 
Tahap pengelompokan ini penting dipahami oleh usaha mikro karena pengelompokan ini bertujuan penting untuk memisahkan antara keuangan pribadi dan usaha. Ini merupakan kendala bagi usaha mikro yang umumnya tidak memisahkan antara pengelolaan keuangan pribadi/rumah tangga dengan usaha. Pengelompokan ini untuk mengetahui apa-apa saja yang termasuk jenis harta (aktiva), hutang (pasiva), modal, biaya-biaya yang dikeluarkan/beban, atau hasil penjualan/pendapatan dan sebagainya. Setelah dikelompokkan berdasarkan itemitem tertentu maka perlu dikelompokkan ke dalam kolom debit dan kredit.

\section{Kesimpulan}

Dari kegiatan pengabdian yang telah dilakukan, maka diperoleh hasil bahwa peserta sangat berminat dengan pelatihan ini. Penambahan pengetahuan bagi peserta tentang pengelolaan keuangan sederhana yang baik dan benar, serta bagaimana membuat laporan keuangan secara cepat dengan menerapkan aplikasi Microsoft Excel.

\section{Daftar Pustaka}

[1] BPS. Badan Pusat Statistik Lubuk Alung. Padang Pariaman: Penerbit Badan Pusat Statistik, 2018.

[2] BPS. Badan Pusat Statistik Lubuk Alung. Padang Pariaman: Penerbit Badan Pusat Statistik, 2018.

[3] S. S. Harahap, Teori Akuntansi Laporan Keuangan. Jakarta: Bumi Aksara, 2002.

[4] S. S. Harahap, Analisis Kritis Atas Laporan Keuangan. Jakarta: PT. Raja Grafindo Persada, 2006.

[5] Sadeli and H. M. Lili, Dasar-dasar Akuntansi. Cetakan Kelima. Jakarta: PT. Bumi Aksara, 2002.

[6] M. Sjadzali, Islam dan Tata Negara: Ajaran, Sejarah dan Pemikiran. Ed. 5, Jakarta: UI-Press, 2010.

[7] Kasmir, Analisis Laporan Keuangan. Rajawali Pers: Jakarta, 2013.

[8] S. Sukirno, Pengantar Ekonomi Makro. Jakarta: Penerbit PT. Raja Grafindo Persada, 2013.

[9] J. F. Weston, and E. E. C Thomas. Dasar-Dasar Manajemen Keuangan. Jakarta: PT. Erlangga, 1990.

[10] F. B. Eugene, and J. F. Houston, Manajemen Keuangan. Edisi kedelapan Jakarta: PT. Erlangga, 2001. 